\title{
The impact of fog nozzle type on the distribution of mass spray density
}

\author{
Wiktor Wąsik ${ }^{1, *}$, Agata Walczak $^{1}$, Tomasz Węsierski ${ }^{1}$ \\ ${ }^{1}$ The Main School of Fire Service, Faculty of Fire Safety Engineering, 52/54 Slowackiego St., 01-629 \\ Warsaw, Poland
}

\begin{abstract}
This study was undertaken to analyze the influence of nozzle type on a mass spray density. The results indicated that the most uniform droplet distribution and spraying area was observed for the impact nozzle P 54. The highest mass spray density and the lowest spraying were noticed for the spiral nozzle TF 6 . The high values of mass spray density for TF 6 nozzle were associated with the high $\mathrm{K}$-factor value and the low spray angle. The results also showed that the construction of spiral nozzles influence the stream structure. The value of average mass spray density was twice as low for CW-50 F nozzle compared to TF 6.
\end{abstract}

\section{Introduction}

Fog nozzles are used in many industrial sectors. A water mist is applied in fire extinguishers for cooling and for absorption of hazardous substances [1-5]. Sprayers, which are used for liquid spraying, utilize different source of energy. For instance, pressure sprayers, among which are eddy and stream sprayers, converse the static pressure into the dynamic pressure using the energy of a fluid, which fills the spraying chamber [6-12]. The most commonly used stream sprayers are so called impact sprayers, which way of action is based on the collision of the head of the stream with a solid surface [13-19]. Therefore, stream sprayers are equipped with deflectors, which shape, and direction determines the shape and quality of spraying. On the contrary, swirl sprayers shape the water stream into a water cone which is thrown outside [20-26]. Depending on the nozzle application, manufacturers concentrate on the macro- and microstructure of the spraying liquid [27-32]. The uniformity of the spraying liquid is determined by the mass spray density [33-38]. The structure of spraying streams depends on numerous factors such as nozzle construction and flow parameters [39-43].

\section{Material and Methods}

The experiments were performer on a dedicated set-up, composed of a cubic chamber with a nozzle localized in the middle, upper part (Fig.1).

\footnotetext{
* Corresponding author: wwasik@sgsp.edu.pl
} 


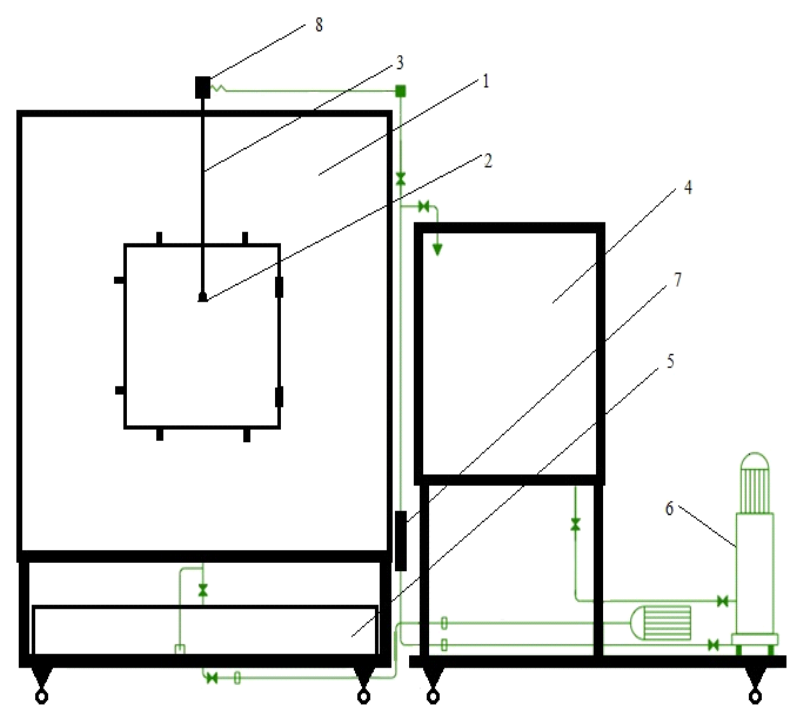

Fig. 1. Experimental stand; 1 - chamber, 2 - nozzle, 3 - telescopic tube, 4 - water tank, 5 - waste tank, 6 - feed pump, 7- pressure sensor, 8 - flowmeter.

The measurement of mass spray density was performed with the use of mass method [44-46] at the distance of $1000 \mathrm{~mm}$ from the analyzed nozzle. Next, the measured values were calculated with the equation (1). The weight of water was metered in a measurement vessel [47-49].

$$
q_{m}=\frac{\Delta m}{\Delta A}
$$

where:

$\mathrm{q}_{\mathrm{m}}$ - mass spray density

$\Delta \mathrm{m}$ - basic water stream $[\mathrm{g} / \mathrm{s}]$

$\Delta \mathrm{A}-$ basic area perpendicular to the spray axis $\left[\mathrm{m}^{2}\right]$

To analyze mass spray density, the following parameters were investigated: mean value $\left(\mathrm{q}_{\mathrm{av}}\right)$, non-uniformity of spray $\left(\Delta \mathrm{q}_{\mathrm{m}}\right)$ eq. (2).

$$
\Delta q_{m}=\frac{q_{\text {max }}-q_{\text {min }}}{q_{m w}}
$$

where:

$\mathrm{q}_{\max }$ - the largest value of $\mathrm{q}_{\mathrm{m}}$ in the measurement

$\mathrm{q}_{\mathrm{min}}$ - the lowest value of $\mathrm{q}_{\mathrm{m}}$ in the measurement

K-factor was determined with the equation (3).

$$
K=\frac{Q}{\sqrt{p}}
$$

where:

$\mathrm{K}-$ factor $\left[\mathrm{dm}^{3} /\left(\min \cdot \mathrm{bar}^{0,5}\right)\right]$

$\mathrm{Q}$ - flow nozzle $\left[\mathrm{dm}^{3} / \mathrm{min}\right]$

$\mathrm{p}$ - nozzle supply pressure [bar]

Three types of nozzles were tested: spiral nozzle TF 6, impact nozzle P 54, swirl axis nozzle with tangent inlet holes in the disc CW-50 F (Fig.2). 


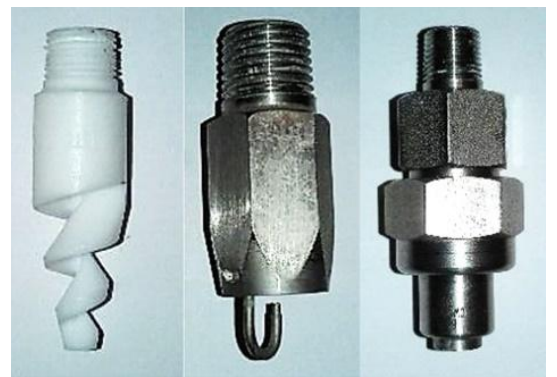

Fig. 2. Nozzle from the left side: TF 6, P 54, CW-50 F.

In the TF 6 nozzle, water flows down the spiral part under pressure and is centrifugally thrown away [50-53]. In the P 54 jet nozzle water is disrupted by a deflector. While, in the CW-50F nozzle water flows out with the use of adjacent discs [54-55].

\section{Results}

The results were presented in Table 1 and on Figs. 3-5.

Table 1. Measurement conditions and obtained results.

\begin{tabular}{|c|c|c|c|c|c|c|}
\hline \multirow{3}{*}{$\begin{array}{l}\text { Measuremen } \\
\text { t conditions } \\
\text { and obtained } \\
\text { results }\end{array}$} & \multicolumn{6}{|c|}{ Nozzle } \\
\hline & \multicolumn{2}{|c|}{ TF 6} & \multicolumn{2}{|c|}{ P 54} & \multicolumn{2}{|c|}{$\mathrm{CW}-50 \mathrm{~F}$} \\
\hline & Value & $\begin{array}{l}\text { Relative } \\
\text { standard } \\
\text { deviation }\end{array}$ & Value & $\begin{array}{l}\text { Relative } \\
\text { standard } \\
\text { deviation }\end{array}$ & Value & $\begin{array}{l}\text { Relative } \\
\text { standard } \\
\text { deviation }\end{array}$ \\
\hline $\begin{array}{l}\text { Flow Q } \\
{\left[\mathrm{dm}^{3} / \mathrm{h}\right]}\end{array}$ & 452.68 & 1.243 & 189.39 & 0.66 & 152.06 & 0.403 \\
\hline $\begin{array}{l}\text { Nozzle supply } \\
\text { pressure } \mathrm{p} \\
\text { [bar] }\end{array}$ & 6.01 & 0.010 & 5.98 & 0.02 & 5.95 & 0.023 \\
\hline $\begin{array}{l}\text { Mean value } \\
\text { mass spray } \\
\text { density } \mathrm{q}_{\mathrm{av}}{ }^{*}\end{array}$ & 76.37 & - & 34.21 & - & 39.38 & - \\
\hline $\begin{array}{l}\text { Largest value } \\
\text { of mass spray } \\
\text { density } \mathrm{q}_{\max }\end{array}$ & 296.511 & - & 56.6143 & - & 135.745 & - \\
\hline $\begin{array}{c}\text { Non- } \\
\text { uniformity of } \\
\text { spray }\left(\Delta \mathrm{q}_{\mathrm{m}}\right) \\
{[-/-]}\end{array}$ & 3.878 & - & 0.994 & - & 3.437 & - \\
\hline Time [s] & 180 & - & 1200 & - & 540 & - \\
\hline $\begin{array}{c}\text { Water } \\
\text { temperature } \\
{\left[{ }^{\circ} \mathrm{C}\right]}\end{array}$ & 21.05 & 0.441 & 21.61 & 0.87 & 21.42 & 0.488 \\
\hline $\begin{array}{c}\text { Ambient } \\
\text { temperature } \\
{\left[{ }^{\circ} \mathrm{C}\right]}\end{array}$ & 21.91 & 0.033 & 21.10 & 0.26 & 21.41 & 0.147 \\
\hline
\end{tabular}

The value of K-factor depended on the nozzle construction and influenced mass spray density. Therefore, increase of K-factor was observed when the nozzle outlet diameter and the flow rate was raised. The highest $\left(3.077\left[\mathrm{dm}^{3} /\left(\mathrm{min}^{\mathrm{bar}}{ }^{0,5}\right)\right]\right)$ and the smallest $(1.039$ $\left.\left[\mathrm{dm}^{3} /\left(\min \cdot \mathrm{bar}^{0,5}\right)\right]\right)$ value of $\mathrm{K}$-factor was observed for TF6 spiral nozzle and CW-50 F 
nozzle, respectively. While, for the shock jet nozzle P 54, K-factor was comparable to CW$50 \mathrm{~F}$ nozzle and equal to $1.291\left[\mathrm{dm}^{3} /\left(\min \cdot \mathrm{bar}^{0,5}\right)\right]$.

A

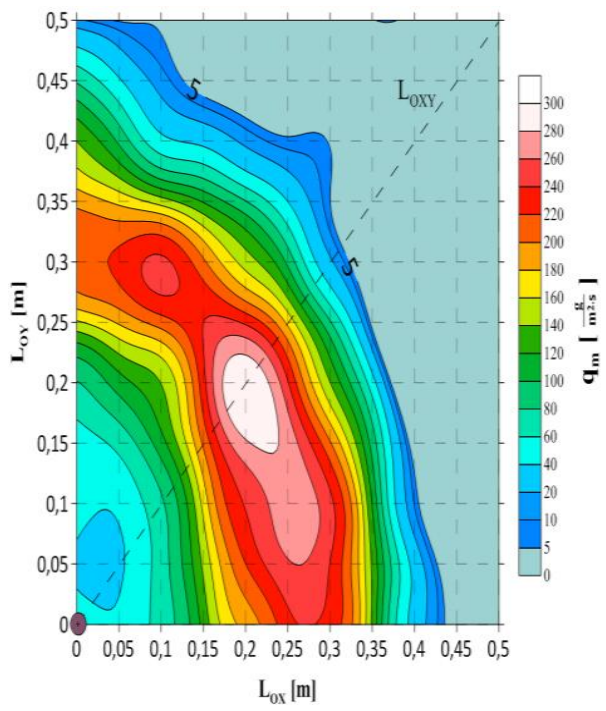

B
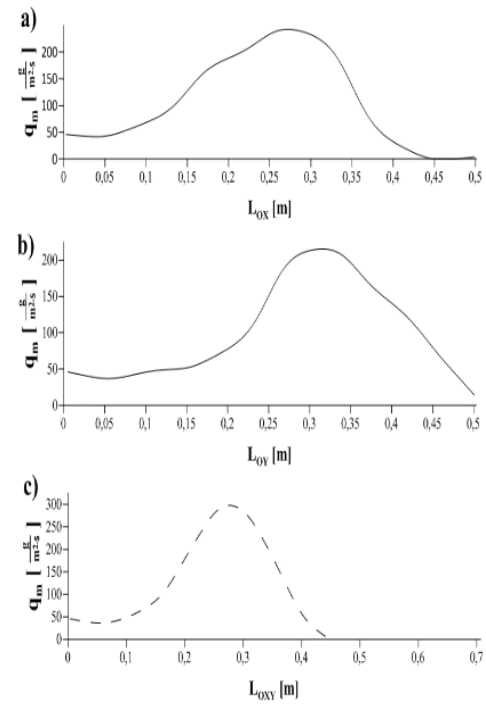

Fig.3. TF 6 nozzle: A - contours of the mass spray density distribution for the nozzle localized in the point $(0,0)$; B - distribution of the mass spray density along the axis: a) OX, b) OY, c) OXY for TF 6 nozzle.

A

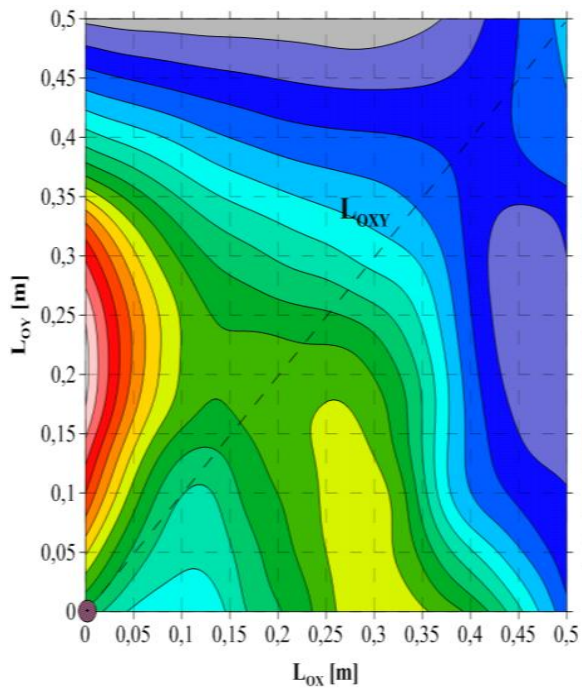

B
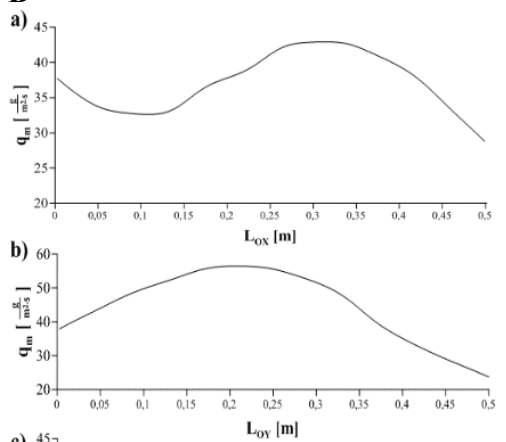

c) ${ }^{45}$

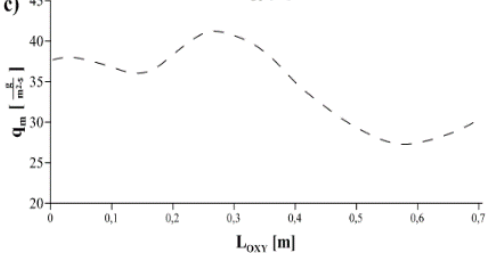

Fig.4. P 54 nozzle: A - contours of the mass spray density distribution for the nozzle localized in the point $(0,0)$; B - distribution of the mass spray density along the axis: a) OX, b) OY, c) OXY for TF 6 nozzle. 
A

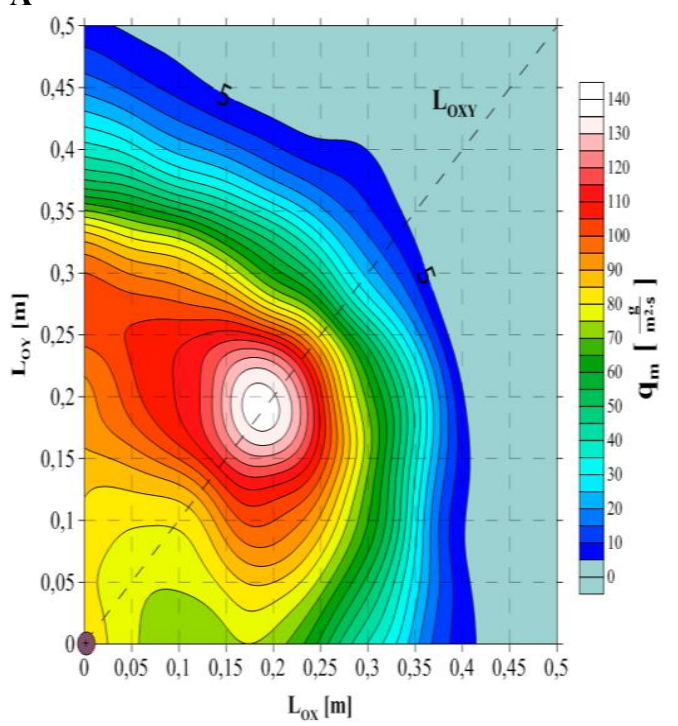

B
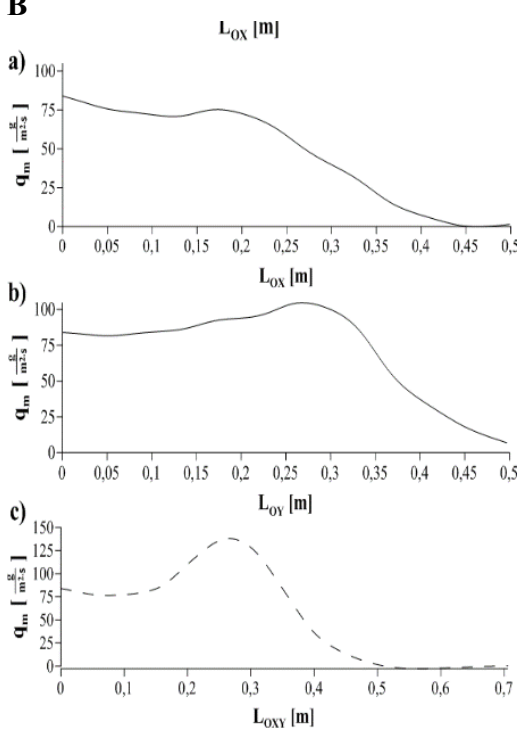

Fig.5. CW-50 F nozzle: A - contours of the mass spray density distribution for the nozzle localized in the point $(0,0)$; B - distribution of the mass spray density along the axis: a) OX, b) OY, c) OXY for TF 6 nozzle.

The results sum up:

- The highest mass spray density was observed for TF 6 nozzle $\left(76.6 \mathrm{~g} /\left(\mathrm{m}^{2} \cdot \mathrm{s}\right)\right.$ and $296.51 \mathrm{~g} /\left(\mathrm{m}^{2} \cdot \mathrm{s}\right)$ for the mean and maximal value, respectively. While for CW-50 F and P 54 mean values were equal to $39.38 \mathrm{~g} /\left(\mathrm{m}^{2} \cdot \mathrm{s}\right)$ and $34.21 \mathrm{~g} /\left(\mathrm{m}^{2} \cdot \mathrm{s}\right)$, respectively. Moreover, the maximum values for those nozzles were equal to $135.75 \mathrm{~g} /\left(\mathrm{m}^{2} \cdot \mathrm{s}\right)$ and $56.61 \mathrm{~g} /\left(\mathrm{m}^{2} \cdot \mathrm{s}\right)$, respectively. High $\mathrm{K}$-factor and the small spray angle indicated a large mass spray density value for TF 6 nozzle. Moreover, the value of both parameters depended on the spatial configuration of TF 6 nozzle.

- $\quad$ The highest spray area was observed for P 54, while the smallest for TF 6.

- The area of TF 6 spray nozzle was symmetrical and had the shape of a ring. The sprayed ring had the maximum value at about $0.3 \mathrm{~m}$ from the nozzle outlet axis (Fig.3A-3B). The width of the sprayed ring was approximately $0.2 \mathrm{~m}$ with mass densities above $100 \mathrm{~g} /\left(\mathrm{m}^{2} \cdot \mathrm{s}\right)$. TF 6 nozzle was characterized with the lower mass spray density directly below the nozzle outlet, which resulted from partial emptiness of a spray nozzle cone.

- The sprayed area of CW-50 F nozzle was symmetrical and had a circular shape. The radius of a circle, in which the mass density exceeded $5 \mathrm{~g} /\left(\mathrm{m}^{2} \cdot \mathrm{s}\right)$ was about $0.45 \mathrm{~m}$. Because of setting one of the water distribution holes inside the nozzle, a single point $(0.2 \mathrm{~m} \times 0.2 \mathrm{~m})$ of increase in the mass spray density was observed (Fig.5A-5B). The nozzle had four such holes arranged symmetrically, hence in all quarters of the spraying area the distributions were the same. CW-50 F nozzle had a full sprayed cone with a relatively equal distribution of water in the sprayed area.

- The mass spray density of P54 nozzle was distributed the most uniformly. The unevenness of spray in the measuring area for this nozzle was equal to 0.994 . TF 6 nozzle had the least uniform water distribution in the sprayed area. The unevenness of spray for this nozzle was equal to 3.878 . 
- An increase in the value of $\mathrm{q}_{\mathrm{m}}$, in the distribution of the mass spray density for P54 nozzle on the OY axis at about $0.2 \mathrm{~m}$, was observed (Fig.4A-4B). It was a result of deflector position, where water was sprayed.

- The high uniformity for P54 nozzle resulted in its high sprayed angle and the method of water spraying. The small diameter of the outlet indicated that the water hit the deflector with high velocity, which improved spray properties.

\section{Conclusions}

The construction of fog nozzles has an impact on the structure of the water stream. The nozzles construction determined the flow factor and the sprayed area. Those parameters have the largest influence on the mass spray density. The results indicated that P54 nozzle had the most uniform droplet distribution and the largest sprayed area. On the contrary, the highest sprayed density and the lowest sprayed area were observed for TF 6 nozzle. The high values of the mass spray density for TF 6 nozzle were associated with the high $\mathrm{K}$ value and the low spray angle. The results also pointed that the construction of spiral nozzles influence the stream structure. The value of the average mass spray density was twice as low for CW-50F compared to TF 6 nozzle.

\section{References}

1. S. Matsuo, Tae-Hun Kim, T. Setoguchi, H. D. Kim, Yeon-Won Lee, J. Therm. Sci. 16 (2007)

2. T. Węsierski, M. Majder-Łopatka, W. Wąsik, Chem. Indust. 96 (2017)

3. T. Wesierski, M. Majder-Lopatka, R. Matuszkiewicz, R. Porowski, Chem. Indust. 91, 3 (2012)

4. J. Qina, W.K. Chow, Proc. Eng. 62 (2013)

5. D. Dmochowski, A. Dmochowska, S. Biedugnis, ROS 17 (2015)

6. M. Tytla, A. Dmochowska, D. Dmochowski, E3S Web of Conferences 44 (2018)

7. A. Zieminska-Stolarska, A. Polanczyk, I. Zbicinski, J. Hydrol. Hydromech. 644, 8 (2015)

8. A. Polanczy, T. Wozniak, M. Strzelecki, W. Szubert, L. Sstefanczyk, Signal Processing SPA 5 (2016)

9. T. Węsierski, M. Majder-Łopatka, W. Wąsik, Ł. Binio, Sci Papers of the Main School of Fire Service, 61 (2017)

10. A. Piechota-Polanczyk, A. Kopacz, D. Kloska, B. Zagrapan, C. Neumayer, A. Grochot-Przeczek, I. Huk, C. Brostjan, J. Dulak, A. Jozkowicz, Oxid Med Cell Longev (2018)

11. K. Kowalska, D. E. Habrowska-Gorczynska, C. Neumayer, M. Bolliger, C. Domenig, A.W. Piastowska-Ciesielska, I. Huk, A. Piechota-Polanczyk, Acta Biochim. Pol. 65 (2018)

12. M. Majder-Lopatka, W. Rogula-Kozlowska, W. Wasik, E3S Web of Conferences 44 (2018)

13. A. Polanczyk, M. Podyma, L. Trebinski, J. Chrzastek, I. Zbicinski, L. Stefanczyk, PLoS One 11 (2016)

14. M. Majder-Lopatka, T. Wesierski, E3S Web of Conferences 46 (2018) 
15. M. Majder-Lopatka, T. Wesierski, W. Wasik, BITP 42, 8 (2016)

16. D. Kloska, A. Kopacz, A. Piechota-Polanczyk, W. Nowak, J. Dulak, A. Jozkowicz, A. Grochot-Przeczek, Vascul. Pharmacol. (2018)

17. A. Piechota-Polanczyk, A. Goraca, Pharmacol. Rep. 64 (2012)

18. A. Piechota, A. Polanczyk, A. Goraca, Pharmacol. Rep. 63 (2011)

19. M. Polka, Z. Salamonowicz, M. Wolinski, B. Kukfisz, Procedia. Eng. 45 (2012)

20. Z. Salamonowicz, W. Jarosz, BITP 3 (2012)

21. A. Piechota, A. Polanczyk, A. Goraca, Pharmacol. Rep. 62 (2010)

22. A. Piechota-Polanczyk, A. Jozkowicz, Curr. Drug Targets 17 (2016)

23. A. Polanczyk, Z. Salamonowicz, E3S Web of Conferences 44, 8 (2018)

24. A. Polanczyk, M. Podgorski, T. Wozniak, L. Stefanczyk, M Strzelecki, Medicina 54, 15 (2018)

25. A. Polanczyk, M. Podgorski, M. Polanczyk, N. Veshkina, I. Zbicinski, L. Stefanczyk, C. Neumayer, Interact. Cardiovasc Thorac. Surg. (2018)

26. Z. Salamonowicz, M. Kotowski, M. Polka, W. Barnat, Chem. Indust. 93 (2014)

27. A. Piechota-Polanczyk, M. Wlodarczyk, A. Sobolewska-Wlodarczyk, M. Jonakowski, A. Pilarczyk, K. Stec-Michalska, M. Wisniewska-Jarosinska, J. Fichna, Dig. Dis. Sci. 62 (2017)

28. A. Piechota-Polanczyk, M. Zielinska, D. Piekielny, J. Fichna, Biomed Pharmacother 84 (2016)

29. A. Polanczyk, A. Piechota-Polanczyk, C. Domenig, J. Nanobachvili, I. Huk, C. Neumayer, Appl. Sci. 8, 14 (2018)

30. M. Salaga, U. Lewandowska, D. Sosnowska, P.K. Zakrzewski, A.I. Cygankiewicz, A. Piechota-Polanczyk, M. Sobczak, P. Mosinska, C. Chen, W.M. Krajewska, J. Fichna, Naunyn Schmiedebergs Arch. Pharmacol. 387 (2014)

31. D. Dmochowski, A. Dmochowska, S. Biedugnis, ROS 17 (2015)

32. A. Polanczyk, M. Podyma, L. Stefanczyk, W. Szubert, I. Zbicinski, J. Biomech. 48 (2015)

33. Z. Salamonowicz, M. Wolinski, M. Sobolewski, M. Polka, Przem. Chem. 93 (2014)

34. Z. Salamonowicz, M. Kotowski, M. Polka, W. Barnat, Bull. Pol. Ac.: Tech. 63 (2015)

35. A. Polanczyk, A. Piechota-Polanczyk, L. Stefanczyk, PlosOne 12 (2017)

36. A. Polanczyk, M. Klinger, J. Nonobachvili, I. Huk, C. Neumayer, Appl. Sci. 8, 12 (2018)

37. A. Polanczyk, M. Strzelecki, T. Wozniak, W. Szubert, L. Stefanczyk, Found. Comp. Decision Sci. 42, 13 (2017)

38. W. Eilenberg, S. Stojkovic, A. Piechota-Polanczyk, C. Kaun, S. Rauscher, M. Groger, M. Klinger, J. Wojta, C. Neumayer, I. Huk, S. Demyanets, Eur. J. Vasc. Endovasc Surg. 51 (2016)

39. H. Zatorski, M. Salaga, M. Zielinska, A. Piechota-Polanczyk, K. Owczarek, R. Kordek, U. Lewandowska, C. Chen, J. Fichna, Naunyn Schmiedebergs Arch. Pharmacol. 388 (2015)

40. A. Polanczyk, P. Wawrzyniak, I. Zbicinski, Drying Technol. 31, 10 (2013)

41. P. Wawrzyniak, A. Polanczyk, I. Zbicinski, M. Jaskulski, M. Podyma, J. Rabaeva, Drying Technol. 30, 10 (2012) 
42. A. Piechota, A. Goraca, J. Physiol. Pharmacol. 62 (2011)

43. W. Jarosz, Z. Salamonowicz, M. Majder-Lopatka, R. Matuszkiewicz, A. Dmochowska, Przem. Chem. 93 (2014)

44. M. Wlodarczyk, A. Sobolewska-Wlodarczyk, A.I. Cygankiewicz, D. Jacenik, A. Piechota-Polanczyk, K. Stec-Michalska, W.M. Krajewska, J. Fichna, M. WisniewskaJarosinska, J. Gastrointestin Liver Dis. 26 (2017)

M. Salaga, L.V. Blomster, A. Piechota-Polanczyk, M. Zielinska, D. Jacenik, A. I.Cygankiewicz, W. M. Krajewska, J.D. Mikkelsen, J. Fichna, J. Pharmacol Exp. Ther. 356 (2016)

45. A. Piechota-Polanczyk, S. Demyanets, O. Nykonenko, I. Huk, M. Mittlboeck, C.M. Domenig, C. Neumayer, J. Wojta, J. Nanobachvili, M. Klinger, Eur. J. Vasc. Endovasc Surg. 45 (2013)

46. A. Polanczyk, M. Podyma, L. Stefanczyk, I. Zbicinski, Chem. Eng. Process. 33, 9 (2012)

47. Z. Salamonowicz, R. Makowski, E3S Web of Conferences 44 (2018)

48. P. Wawrzyniak, M. Podyma, I. Zbicinski, Z. Bartczak, A. Polanczyk, J. Rabaeva, Drying Techn. 30, 9 (2012)

49. Z. Salamonowicz, M. Majder-Lopatka, BITP 30 (2013)

50. Z. Orzechowski, J. Prywer, Generation and application of the sprayed liquid First edition (WNT, Warsaw, 2008)

51. J.J. Park, M.W. Lee et al, J. Therm. Spray Tech. 20 (2011)

52. S.H. Yoon et al, J. Mech. Sci. Techn. 25 (2011)

53. M. Frey, K. Makowka, T. Aichner, CEAS Space J. 9 (2017)

54. A. Javed, D. Chakraborty, J. Inst. Eng. India Ser. C. 98 (2017) 